Journal Of Al Azhar University Engineering Sector

Vol. 12, No. 43, April 2017, 501-510

\title{
EFFECT OF NANO-SILICA, SILICA FUME, CEMENT CONTENT AND CURING CONDITIONS ON THE CONCRETE COMPRESSIVE STRENGTH AT 7 AND 28 DAYS
}

\author{
S. S. E. Ahmad ${ }^{1}$, El-Shikh M. Yousry ${ }^{2}$ and Mohamed.A.R. Elmahdy ${ }^{3}$ \\ ${ }^{1}$ Mat.Dept., Faculty of Engineering Zagazig University, Egypt, \\ ${ }^{2}$ Str.Dept., Faculty of engineering, El mansura University, Egypt, \\ ${ }^{3}$ Demonstrator, Misr Higher Institute of Eng.\&Tech, Elmansura, Egypt,
}

\begin{abstract}
Recently there is a strong trend in engineering researches in the field of engineering materials for the production of high and ultra- high strength concrete. Using different additives which are added to the concrete mix reduced the water cement ratio and caused an increase in the concrete strength. As well as the use of ultra-fine materials such as Nano-silica increase the strength of concrete dramatically. In spite of the success of this research to get to compressive strength up to $150 \mathrm{MPa}$ or more, however, many problems have found in the mechanical behavior of these concretes, which turned into a decrease in the fracture toughness significantly. An experimental program was designed to investigate the effect of cement content, silica fume and Nano silica percent, and curing on the compressive strength of concrete at different curing ages. The results of the present work clearly showed an increase in the value of 28-day concrete compressive strength with existence of silica and Nano silica. Steam curing, also, led to an improvement in compressive strength as compared to water curing.
\end{abstract}

Keywords: Nano-silica, High strength concrete, steam curing, cement contents

\section{INTRODUCTION}

The compressive strength of concrete depends on the water to cement ratio, degree of compaction, ratio of cement to aggregate, bond between mortar and aggregate, and grading, shape, strength and size of the aggregate. An experiment was conducted to determine the effect of different sizes of different aggregates for concrete production on the compressive strength of concrete. The results showed that the smallest coarse aggregate size gave the highest compressive strength and lowest slump at constant water/cement ratio $[1,2,3]$.

The addition of supplementary cementitious materials such as silica fume reduces both pore sizes and porosity, and increase strength. Silica fume is very reactive therefore it increases both the early and later age strength by affecting cement hydration immediately. The compressive, split-tensile and flexural strengths of concrete are increased. The interfacial transition zone can be improved by the addition of pozzolanic materials like silica fumes, fly ash, GGBS etc. which reacts with $\mathrm{Ca}(\mathrm{OH}) 2$ crystals forming $\mathrm{CSH}$. Silica fume particles consume $\mathrm{Ca}(\mathrm{OH}) 2$ available in transition zone and makes it dense and uniform $[4,5,6]$.

The influence of curing regimes on compressive strength of ultra-high strength concrete was studied in several works. It is suggested that $48 \mathrm{hrs}$ thermal curing followed by water curing strength gains the more than $200 \mathrm{MPa}$. The choice of ingredients and curing regimes plays 
dominant role in high strength concrete and in high performance concrete. Samples were casted by Praphat et al, achieved compressive strength of $170 \mathrm{MPa}$ under a combination of normal water curing, hot water curing and hot air curing. Thermal curing regime enhances the micro structural changes of hydrated structure. Increasing temperature and duration causing formation of different C-S-H gel crystal such as Tobermorite, xonotlite and scwatite. It is observed that thermal curing regime increase the compressive strength up to $40 \%$ nearly when sample compared with that of normal water curing. At normal water curing, pozzalanic reaction of silica fume and quartz powder is not activated, only they act as filler material [7]. Steam curing at ambient pressure is the most common technique among the accelerated curing methods of concrete. In applications, such as pre-cast concretes and pre-stressed reinforced concretes, which require high mechanical performances at very early ages, the steam curing enables concretes which normally have slower strength gain, such as fly ash concretes, to achieve faster strength gain at the required levels. The steam-cured concretes showed 4 to $15 \%$ higher 1-day compressive strength than their air-cured counterparts due to the acceleration of the $\mathrm{CSH}$ gel formation. The 28 and 90-day compressive strengths of the steam-cured concretes were similar to those of air-cured concretes when using the same type of aggregate $[8,9]$.

Over the past decade, the definition of nanoparticles has been controversial. Nanoparticles are commonly defined as objects with a diameter less than $30 \times 10^{-9} \mathrm{~m}$, but no clear size cut-off exists, and this usual boundary does not appear to have a solid scientific basis. Nano-silica is being incorporated into the cement to give enhanced mechanical property, lower porosity and permeability, which are crucial factors for increased durability. Several studies show that the application of Nano silica in cementitious system improves the compressive strength at early age of hydration. The addition of nanomaterials not only shortened the dormant period but also lead to an early appearance of the second peak. The nano-SiO2 mainly contributed to the early strength development of UHSC before $7 \mathrm{~d}$. The $\mathrm{CH}$ content in UHSC series dropped significantly with the increase of nano-SiO2 content. Nano-SiO2 demonstrated nucleation and filling effects and resulted in less porous and more homogeneous structure $[10,11]$.

It is a common practice to use high cement content for achieving higher strength concrete. Strength is considered to be a function of w/c and independent of cement content for a given w/c, therefore increasing cement content does not affect strength. Furthermore, according to Abrams rule, paste content does not affect strength although it is affected by the paste quality [12].

In the way to produce high or ultra-high strength concrete, it is important to investigate the effect of cement content, silica fume and Nano silica percent, and curing on the compressive strength of concrete at different curing ages. Therefore, an experimental program was designed to study these effects.

\section{EXPERIMENTAL PLAN}

The details descriptions of the materials used through this investigation, particularly cement, aggregate, silica fume, water and chemical admixtures are given in this section. The used materials in the current research were chosen from the available materials in Egypt. The experimental plan includes preparation of materials, test specimens, mixing, casting, curing, and testing of hardened concrete.

\section{Materials}

Ordinary Portland Cement (OPC) (CEM I 52.5 N) produced by Bani Sweif cement factory was used in this study. The different laboratory tests were conducted on cement conforms to Egyptian Standards (ES 4756-1/2009) [13]. The chemical analysis and calculated chemical composition of the used cement are given in tables (1) and (2). The chemical analysis was conducted in Housing \& Building National Research Center (HBRC). The physical and mechanical properties of cement are shown in table (3). 
Table (1) Chemical composition of the cement

\begin{tabular}{|c|c|}
\hline Oxide composition & Percent by Weight $(\%)$ \\
\hline Silicon Oxide $\left(\mathrm{SiO}_{2}\right)$ & 21.58 \\
\hline Aluminum Oxide $\left(\mathrm{Al}_{2} \mathrm{O}_{3}\right)$ & 4.94 \\
\hline Ferric Oxide $\left(\mathrm{Fe}_{2} \mathrm{O}_{3}\right)$ & 3.56 \\
\hline Calcium Oxide $(\mathrm{CaO})$ & 61.09 \\
\hline Magnesium Oxide $(\mathrm{MgO})$ & 1.65 \\
\hline Sulpher Trioxide $\left(\mathrm{SO}_{3}\right)$ & 3.22 \\
\hline Loss on Ignition $(\mathrm{L.O.I})$ & 2.60 \\
\hline Sodium Oxide $\left(\mathrm{Na}_{2} \mathrm{O}\right)$ & 0.50 \\
\hline Potassium Oxide $\left(\mathrm{K}_{2} \mathrm{O}\right)$ & 0.18 \\
\hline Total & 99.91 \\
\hline Insoluble Residue $(\mathrm{IR})$ & 1.71 \\
\hline
\end{tabular}

Table (2) Calculated compounds of cement

\begin{tabular}{|c|c|}
\hline Name of compounds & Content \% \\
\hline Tricalcium Silicate $\mathrm{C}_{3} \mathrm{~S}$ & 37.1637 \\
\hline Dicalcium Silicate $\mathrm{C}_{2} \mathrm{~S}$ & 33.913 \\
\hline Tricalcium Aluminate $\mathrm{C}_{3} \mathrm{~A}$ & 7.0746 \\
\hline Tetracalcium Aluminoferrite $\mathrm{C}_{4} \mathrm{AF}$ & 10.8224 \\
\hline
\end{tabular}

Table (3) Physical and mechanical properties of the cement

\begin{tabular}{|c|c|c|c|}
\hline \multicolumn{2}{|l|}{ Test } & Test result & (ES 4756-1/2009) limits \\
\hline \multicolumn{2}{|l|}{ specific gravity } & 3.15 & ---- \\
\hline \multicolumn{2}{|c|}{ Specific surface area $\quad\left(\mathrm{cm}^{2} / \mathrm{gm}\right)$} & 3600 & $\geq 2750$ \\
\hline \multirow{2}{*}{$\begin{array}{c}\text { Setting time } \\
\text { (Vicat apparatus) (min) }\end{array}$} & Initial & 75 & $\geq 45 \mathrm{~min}$ \\
\hline & Final & 190 & $\leq 10$ hours \\
\hline \multicolumn{2}{|c|}{ Compressive strength 2 days ( $\mathrm{MPa})$} & 23.5 & $\geq 20 \mathrm{MPa}$ \\
\hline \multicolumn{2}{|c|}{ Compressive strength 28days (MPa) } & 54.4 & $\geq 52.5 \mathrm{MPa}$ \\
\hline \multicolumn{2}{|c|}{ Consistency of standard cement paste } & $\mathrm{W} / \mathrm{C}=28 \%$ & $26 \%-33 \%$ \\
\hline
\end{tabular}

All aggregates used in this research are locally available; it consisted of basalt and quartz. Coarse aggregate was washed 7 days before being used and left dry to avoid the effect of fine materials in aggregate. The coarse aggregates used in the experimental work is Basalt 1 from Beni sweif with a maximum nominal size $10 \mathrm{~mm}$. Testing of the used coarse aggregate was complied with the Egyptian Standards ES 1109-2008 [14]. Table (4) shows the grading of the used coarse aggregate. The physical properties of the used coarse aggregate are given in table (5)

Table (4) grading of the coarse aggregate

\begin{tabular}{|c|c|c|c|c|c|c|}
\hline Sieve size (mm) & 37.5 & 20 & 10 & 5 & 2.36 & 1.18 \\
\hline Passing (\%),Basalt 1 & 100 & 99.3 & 96.2 & 11.7 & 1.5 & 0.22 \\
\hline
\end{tabular}


Table (5): The physical properties of the used coarse aggregate

\begin{tabular}{|c|c|c|}
\hline Property & Basalt 1 & Limits* \\
\hline Specific weight & 2.7 & - \\
\hline Bulk density (t/m3) & 1.47 & - \\
\hline Coefficient of abrasion (Loss Angloss) \% & 18 & Less than 30 \\
\hline Coefficient of impact \% & 15 & Less than 30 \\
\hline Crushing value \% & 26 & Less than 30 \\
\hline Absorption \% & 1.6 & Less than 2.5 \\
\hline Clay and fine dust content \% & 0.8 & Less than 3.0 \\
\hline
\end{tabular}

*The limits according to Egyptian Specification No (1109/2008).

Crushed Quartz is used as fine aggregate. Testing of the used fine aggregate was complied with the Egyptian Standards ES 1109-2008 [14]. The physical properties of used fine aggregate are given in table (6).

Table (6): The physical properties of the fine aggregate

\begin{tabular}{|c|c|c|}
\hline Property & Crushed Quartz & Limits* \\
\hline Specific weight & 2.5 & - \\
\hline Bulk density (t/m3) & 1.52 & - \\
\hline Fineness modulus & 3 & - \\
\hline Material finer than No 200 sieve $\%$ & 2.62 & Less than 3\% \\
\hline
\end{tabular}

*The limits according to Egyptian Specification No (1109/2008).

The silica fume used in this research as a mineral admixture was brought from Sika Company in Egypt. Table (7) show the physical composition of the used silica fume as obtained from the manufacture data sheet.

Table (7): The physical properties of the used silica fume

\begin{tabular}{|c|c|}
\hline Property & Result* \\
\hline Surface area $\left(\mathrm{cm}^{2} / \mathrm{gm}\right)$ & 170000 \\
\hline Particle size,$\mu \mathrm{m}$ & 8.00 \\
\hline Specific gravity & 2.20 \\
\hline
\end{tabular}

*By the manufacture data sheet.

Table (8): Properties of the Nano silica

\begin{tabular}{|c|c|}
\hline Property & Result \\
\hline Particle size $\left(\mathrm{x} 10^{-9} \mathrm{~m}\right)$ & $5: 20$ \\
\hline Surface area $\left(\mathrm{cm}^{2} / \mathrm{gm}\right)$ & 2400000 \\
\hline Density $\left(\mathrm{Kg} / \mathrm{m}^{3}\right)$ & 505 \\
\hline Purity $\%$ & 99.8 \\
\hline Color & white \\
\hline
\end{tabular}

The used Nano silica (SiO2, $99.8 \%$ ) was brought from National Research Center. Table (8) shows the properties of Nano Silica used in this work. A high performance superplasticizer concrete admixture Sika Viscocrete - 3425 was used in this work, it is a third generation superplasicizer for homogenous concrete, it meets the requirements for superplasticizers according to ASTM-C-494 types G and F and BS EN 934 part 2:2001. Using this type of superplasticizers we can obtain extremely powerful water reduction and resulting in high 
density and strengths. It, also, improves shrinkage, creep behavior and water impermeability. The used dosage of superplasticizers was constant in all mixes equal $4.5 \%$ of the weight of cement, Table (9) show the properties of superplasticizers used in this work.

Table (9): Properties of the superplasticizers
\begin{tabular}{|c|c|}
\hline Property & Result* \\
\hline Appearance / color & Clear liquid \\
\hline Density (Kg/lit) & 1.08 \\
\hline PH value & 4.0 \\
\hline Solid content (\% by weight) & 40 \\
\hline
\end{tabular}

*By the manufacture data sheet.

Clean tap drinking water was used in mixing. The water to cement ratio W/C was 0.20 in all beams to get ultra-high strength concrete.

\section{Mix Design, casting and curing}

The preliminary mix Proportions were determined and the weight of each component to produce one cubic meter of concrete can be calculated based on absolute volume method. The mixes configuration and experimental program are given in table (10).

Table (10): Mixes configuration for the present experimental program

\begin{tabular}{|c|c|c|c|c|c|c|c|c|c|}
\hline \multirow{2}{*}{ Mix } & C.C & water & SF & $\mathrm{N}$ & \multicolumn{2}{|c|}{ Aggregate Type } & \multicolumn{2}{|c|}{ Aggregates (100\%) } & \multirow{2}{*}{ Curing } \\
\cline { 2 - 10 } & $\mathrm{Kg} / \mathrm{m}^{3}$ & Lit $/ \mathrm{m}^{3}$ & $\% \mathrm{C}$ & $\% \mathrm{C}$ & Coarse & Fine & Coarse (\%) & Fine(\%) & \\
\hline M1 & 500 & 100 & $10 \%$ & $4.00 \%$ & Basalt 1 & Quartz & $50 \%$ & $50 \%$ & Steam \\
\hline M2 & 500 & 100 & $10 \%$ & $4.00 \%$ & Basalt 1 & Quartz & $50 \%$ & $50 \%$ & Water \\
\hline M3 & 500 & 100 & $10 \%$ & $0.00 \%$ & Basalt 1 & Quartz & $50 \%$ & $50 \%$ & Steam \\
\hline M4 & 800 & 160 & $10 \%$ & $4.00 \%$ & Basalt 1 & Quartz & $50 \%$ & $50 \%$ & Steam \\
\hline M5 & 800 & 160 & $10 \%$ & $0.00 \%$ & Basalt 1 & Quartz & $50 \%$ & $50 \%$ & Steam \\
\hline M7 & 800 & 160 & $10 \%$ & $0.00 \%$ & Basalt 1 & Quartz & $50 \%$ & $50 \%$ & Water \\
\hline M8 & 800 & 160 & $20 \%$ & $0.00 \%$ & Basalt 1 & Quartz & $50 \%$ & $50 \%$ & Steam \\
\hline
\end{tabular}

Mixing of concrete components was done by using a horizontal mixer. The aggregates (coarse and fine), cement, silica fume, were added into the mixer in dry state and mixed for 2 minutes. The mixing water and superplasticizer were added gradually and mixed for another 3 minutes to get uniform and homogeneous mixes. The properties of fresh concrete were measured just after mixing; concrete was removed out from the mixer, slump flow and T50cm time test were carried out.

The fresh concrete taken from the mixer was placed in the molds. As result of using high percentage of superplasticizer in this work, the consistency is similar to self-compacting concrete. Therefore, the concrete was placed in the molds under its own weight without any vibration effort. The specimens were kept in the molds for 24 hours in air. The specimens were removed from the molds and stored under fresh water until the test. For steam curing the specimens were removed from the molds and cured at atmospheric pressure using a steam resulting from boiling water at temperature of $100^{\circ} \mathrm{C}$ for 3 days. After that the specimens were left to cool for $2 \mathrm{hrs}$ and then cured using tap fresh water until performing compressive test.

Test specimens

Twelve cubes $(10 \times 10 \times 10 \mathrm{~cm})$ were cast for each concrete mix. All the specimens were removed from the curing tank before testing age and left about 2 hours to dry in laboratory. The compressive strength after 7,28 and 56 days were measured. Three specimens from each mixture were tested at each testing age. The compressive test was performed in accordance with BS EN 12390-3:2002 [15], by using hydraulic testing machine with a capacity of 200 tons and accuracy of 0.5 ton in concrete laboratory, faculty of engineering, Mansoura University. 


\section{RESULTS AND DISCUSSION}

\section{Effect of Nano -Silica content}

Figures $1 \mathrm{a}$ and $1 \mathrm{~b}$ show the effect of incorporating $4 \%$ Nano silica on concrete compressive strength at 7 and 28 days, with cement content $500 \mathrm{Kg} / \mathrm{m} 3$, respectively. The mixes M3 and M1 have the same aggregate, w/c ratio, and curing conditions. The data in figures clearly show an improvement in the compressive strength due to addition of Nano silica by $4 \%$. Where, the strength at 7 days increased from 530 to $557 \mathrm{Kg} / \mathrm{cm} 2$ by about $5.1 \%$. While the strength at 28 days increased from 587 to $656 \mathrm{Kg} / \mathrm{cm} 2$ by about $11.75 \%$. These result were attributed to the well-known physical role of Nano silica at 7 days and may be to the physical and pozolanic role at 28 days.
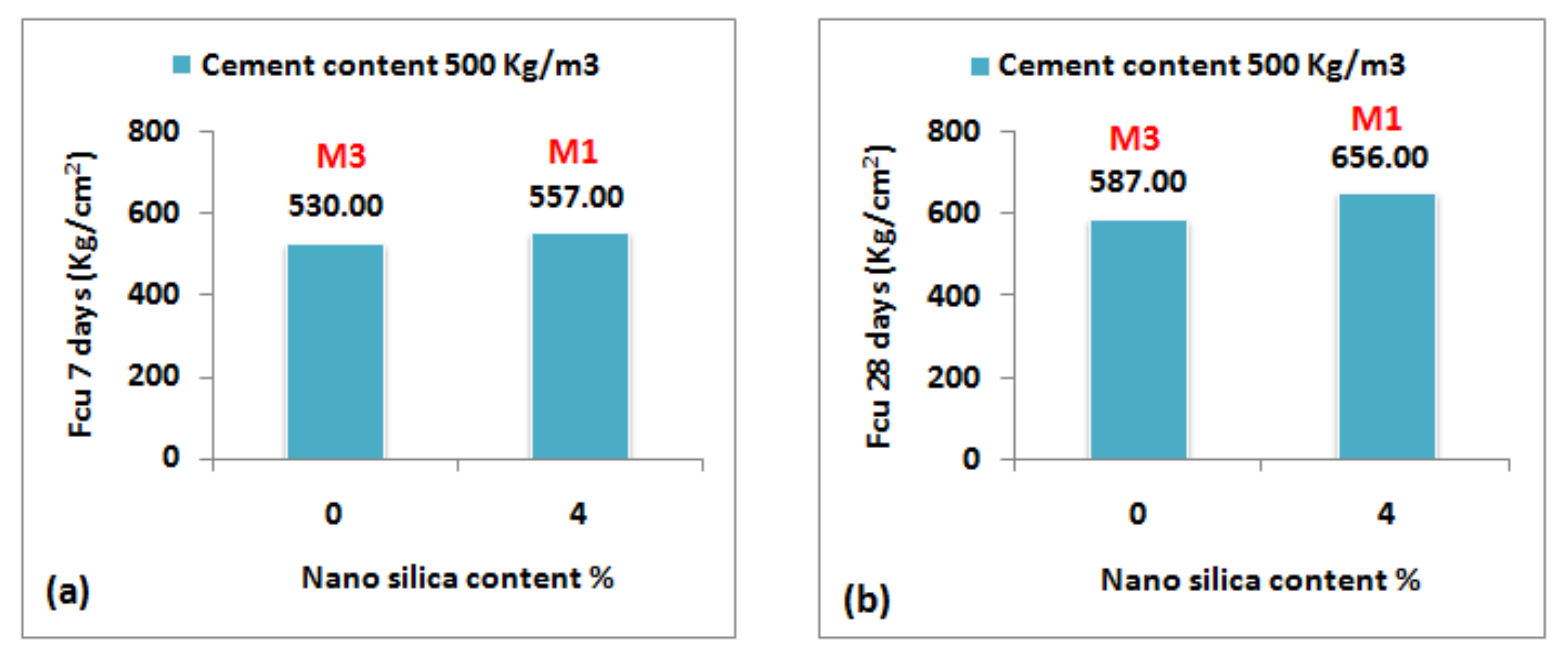

Fig (1) Effect of Nano silica on concrete compressive strength, (a) at 7 days and (b) at 28 days with cement content $500 \mathrm{Kg} / \mathrm{m}^{3}$

A similar result was noticed in figure $2 \mathrm{a}$ and $2 \mathrm{~b}$ for cement content $800 \mathrm{Kg} / \mathrm{m}^{3}$. The mixes M4 and M5 have the same aggregate, w/c ratio, and curing conditions. The data in figures clearly show an improvement in the compressive strength due to addition of Nano silica by $4 \%$. Where, the strength at 7 days increased from 565 to $577 \mathrm{Kg} / \mathrm{cm}^{2}$ by about $2.1 \%$. While the strength at 28 days increased from 624 to $695 \mathrm{Kg} / \mathrm{cm}^{2}$ by about $11.4 \%$. These result were attributed to the well-known physical role of Nano silica at 7 days and may be to the physical and pozolanic role at 28 days.
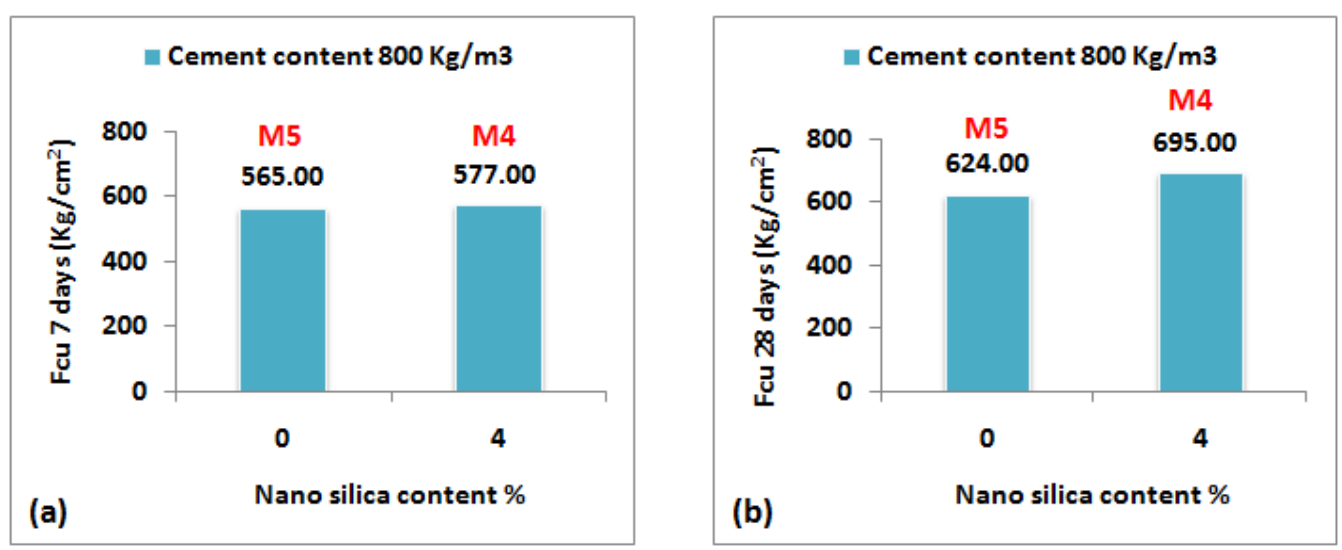

Fig (2) Effect of Nano silica on concrete compressive strength, (a) at 7 days and (b) at 28 days with cement content $800 \mathrm{Kg} / \mathrm{m}^{3}$ 
Several studies show that the application of Nano silica in cementitious system improves the compressive strength at early age of hydration. Nano-silica is being incorporated into the concrete mix to give enhanced mechanical property, lower porosity and permeability, which are crucial factors for increased strength at 7 days. Z. Wu et al. [10] concluded that nano-SiO2 decreased the follow ability and accelerated the heat of hydration. The addition of nanomaterials not only shortened the dormant period but also lead to an early appearance of the second peak. As mention by [10], the $\mathrm{CH}$ content in the concrete containing nano-SiO2 dropped significantly with the increase of nano-SiO2 content. Nano-SiO2 demonstrated nucleation and filling effects and resulted in less porous and more homogeneous structure. This finding may be explaining the present results in our work. Nano silica addition significantly alters the proportion of low and high stiffness $\mathrm{C}-\mathrm{S}-\mathrm{H}$. A similar result was reported by Singh et al., [11].

\section{Effect of silica fume content}

The very small particles of silica fume can enter the space between the particles of cement and thus improve packing. The compared concrete mixes M5 and M8 have the same aggregate grading, the same water to cement ratio 0.20, the same Nano-silica content $0 \%$ and the same super plasticizer content $4.5 \%$. At age of 7 days there is insignificant increase in compressive strength, about $1.59 \%$, but at age of 28 days the compressive strength showed small increase, about $3.84 \%$, as shown in fig $3 \mathrm{a}$ and $3 \mathrm{~b}$.
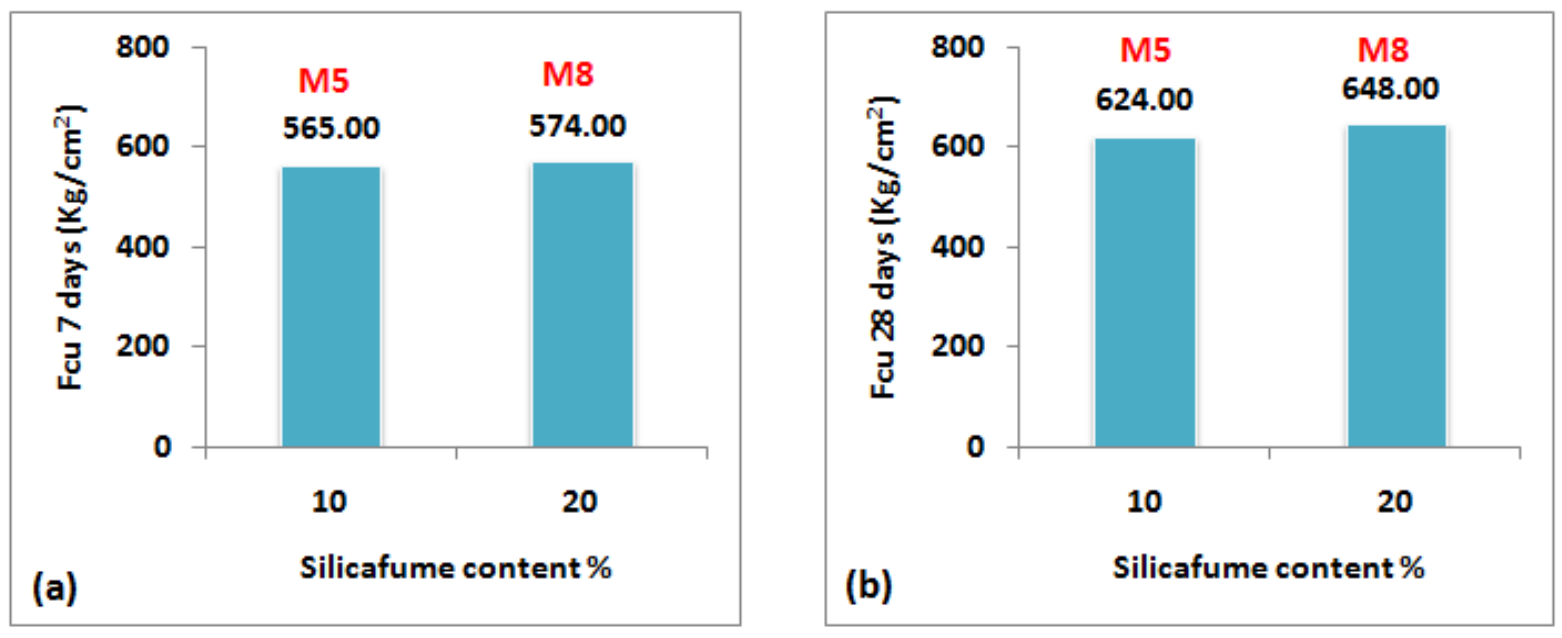

Fig (3) Effect of silica fume content on concrete compressive strength, (a) at 7 days and (b) at 28 days with cement content $800 \mathrm{Kg} / \mathrm{m}^{3}$

The data in figure (3) clearly show that there is a little enhancement in early compressive strength of concrete, at 7 days, as the silica fume content increases from $10 \%$ to $20 \%$. The same results were noted in [4 and 5]. Lakshmi, et al. [5] in their study concluded that, with the addition of mineral admixtures, the compressive, split-tensile and flexural strengths of concrete are increased. Increase the percent of silica fume cause an increase in compressive strength. K.Anusha, S.Kesavan [4] reported that one of the most beneficial uses for silica fume in concrete is because of the chemical and physical properties and it is a very reactive pozzolan. Concrete containing silica fume can have very high strength and can be very durable.

\section{Effect of cement content}

In general, the increase in cement content causes an increasing in the compressive strength of concrete. Figures $4 \mathrm{a}, 4 \mathrm{~b}, 4 \mathrm{c}$, and $4 \mathrm{~d}$ show the effect of cement content on the compressive strength with and without using Nano-silica additions. For mixes with Nano-silica, (M1 and $\mathrm{M} 4)$, the increase of cement content from $500 \mathrm{Kg} / \mathrm{m}^{3}$ to $800 \mathrm{Kg} / \mathrm{m}^{3}$ caused an increase in 
compressive strength by about $3.5 \%$ at 7 days and by $5.9 \%$ at 28 days. For mixes without Nano silica, the increase in cement content from $500 \mathrm{Kg} / \mathrm{m}^{3}$ to $800 \mathrm{Kg} / \mathrm{m}^{3}$ caused an increase in compressive strength by about $6.6 \%$ at 7 days and by $6.3 \%$ at 28 days. It clear from the result in figure (4) that the percentage increases in compressive strength at 7 and 28 days due to increase in cement content is more pronounced in the mixes without Nano silica. This behavior may be attributed to the absence of pozolanic effect especially at early ages.
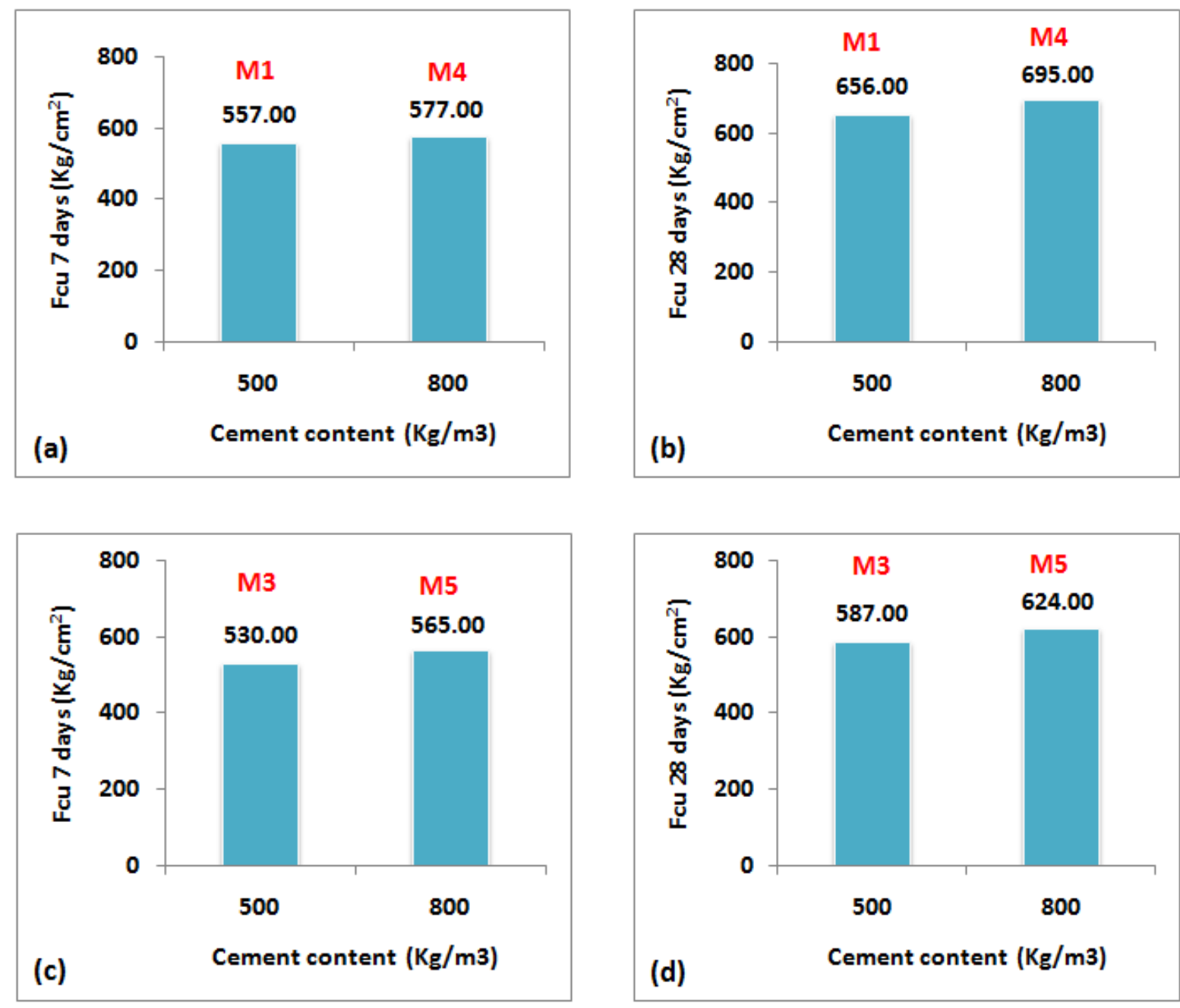

Fig (4) Effect of cement content on concrete compressive strength with and without Nano silica

\section{Effect of curing type}

Figures $5 \mathrm{a}$ and $5 \mathrm{~b}$ show comparison between the compressive strength for mixes M1 and M2 at ages 7 and 28 days respectively. The cement content in two mixes was $500 \mathrm{Kg} / \mathrm{m}^{3}$ and the Nano-silica content was 4\%. The specimens of M1 were cured firstly by steam for 3 days and followed by water curing until test. On the other hand, the specimen of M2 was cured in water only until test. The data in figures clearly show a remarkable increase in compressive strength at two ages of test due to steam curing. The 7-days compressive strength increased by about $39.25 \%$ whiles the 28 -day compressive strength increased by about $50.1 \%$. 

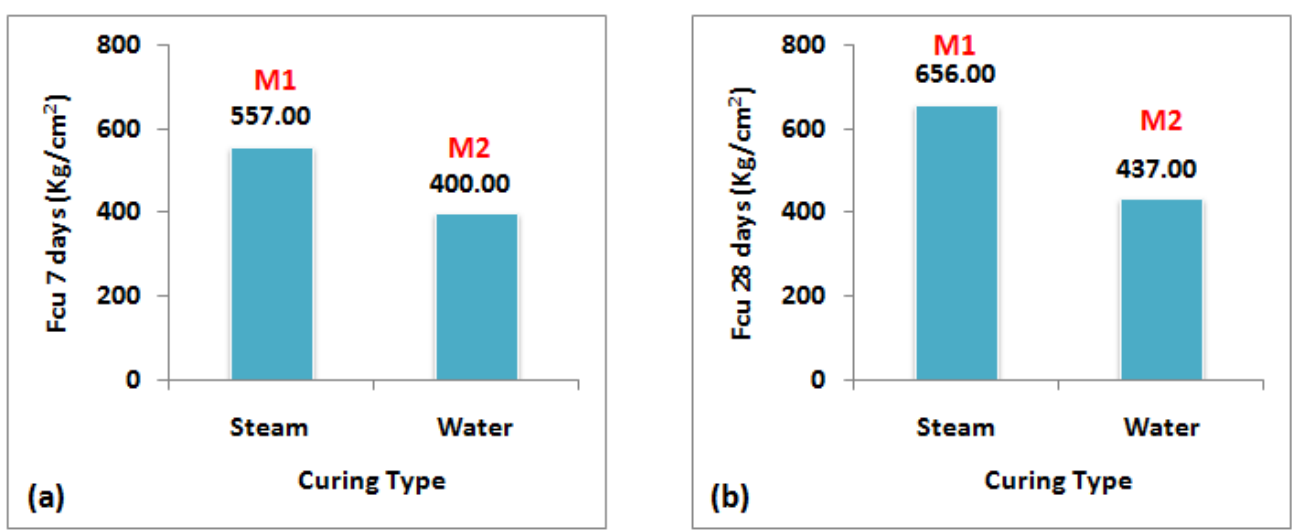

Fig (5) Effect of curing Type on compressive strength, (a) at 7 days and (b) at 28 days with cement content $500 \mathrm{Ko} / \mathrm{m} 3$

Figures $6 \mathrm{a}$ and $6 \mathrm{~b}$ show comparison between the compressive strength for mixes M5 and M7 at ages 7 and 28 days respectively. The cement content in two mixes was $800 \mathrm{Kg} / \mathrm{m}^{3}$ and the Nano silica content was $0 \%$. The specimens of M5 were cured firstly by steam for 3 days and followed by water curing until test. On the other hand, the specimens of M7 were cured by water only until test. The data in figures clearly show a remarkable increase in compressive strength at two test ages due to steam curing. The 7-days compressive strength increased by about $20.7 \%$ whiles the 28-day compressive strength increased by about $30 \%$.
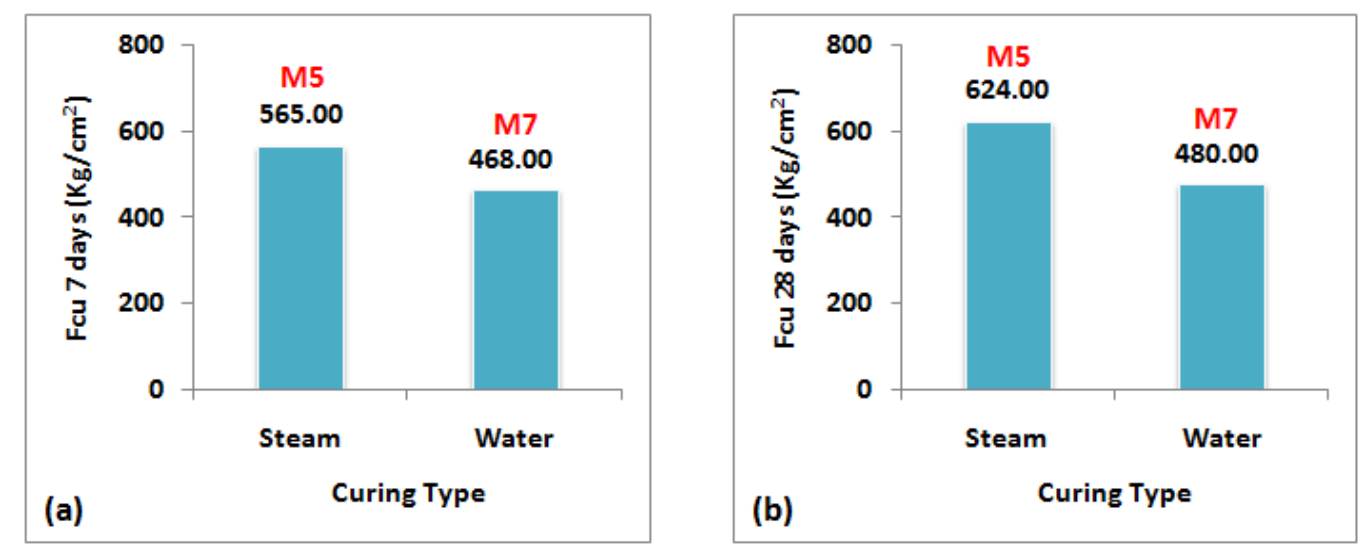

Fig (6) Effect of curing type on compressive strength, (a) at 7 days and (b) at 28 days with cement content $800 \mathrm{Kg} / \mathrm{m3}$

It is clear from the results in Figures 5 and 6 that the steam curing is more effective with existence of Nano silica in mixes M1 and M2. Steam curing at normal pressure is the most common technique among the accelerated curing methods of concrete. In applications, such as pre-cast concretes and pre-stressed reinforced concretes, which require high mechanical performances at very early ages, the steam curing enables concretes to achieve faster strength gain at the required levels. Thermal curing regime enhances the micro structural changes of hydrated cement. Increasing temperature and duration causing formation of different C-S-H gel crystal such as Tobermorite, xonotlite and scwatite. It is observed that thermal curing regime increase the compressive strength up to $40 \%$ nearly when sample compared with normal water curing. At normal water curing, pozzalanic reaction of silica fume and quartz powder is not activated, only they act as filler material $[7,8,9]$.

\section{CONCLUSIONS}

The results in the present investigation reveal several conclusions:

1- The results in this work show an improvement in the compressive strength due to addition of Nano silica by $4 \%$. Where, the strength at 7 days increased by about $2.1 \%$ whiles the strength at 28 days increased by about $11.4 \%$ for water curing condition. 
2- Addition $10 \%$ silica fume led to insignificant increase in compressive strength at 7 days but at age of 28 days the compressive strength showed small increase

3- For mixes with Nano-silica the increase of cement content from $500 \mathrm{Kg} / \mathrm{m}^{3}$ to 800 $\mathrm{Kg} / \mathrm{m}^{3}$ caused an increase in compressive strength by about $3.5 \%$ at 7 days and by $5.9 \%$ at 28 days. On the other hand, mixes without Nano silica showed an increase in compressive strength by about $6.6 \%$ at 7 days and by $6.3 \%$ at 28 days.

4- The results in this investigation show a remarkable increase in compressive strength at 7 and 28 days due to steam curing. The 7-days compressive strength increased by about $39.25 \%$ whiles the 28-day compressive strength increased by about $50.1 \%$ for mixes containing Nano silica.

\section{REFERENCES}

[1] Anthony Woode, David Kwame Amoah, Issaka Ayuba Aguba, Philip Ballow" The Effect of Maximum Coarse Aggregate Size on the Compressive Strength of Concrete Produced in Ghana " ISSN 2224-5790 (Paper) ISSN 2225-0514, Vol.7, No.5, 2015.

[2] Bhikshma, V. \& Florence, G. A., "Studies on effect of maximum size of aggregate in higher grade concrete with high volume fly ash", Asian Journal of Civil Engineering 14 (1), 101-109,2013.

[3] Kumar, R. P.1 \& Krishna, R.M.V, "A Study on the Effect of Size of Aggregate on the Strength and Sorptivity Characteristics of Cinder Based Light Weight Concrete", Research Journal of Engineering Sciences 1(6), 27-35, 2012.

[4] K.Anusha, S.Kesavan "A study on behavior of ultra-high strength concrete at elevated temperatures" International journal of engineering sciences \& Emerging technologies,. ISSN: 22316604 Volume 7, Issue 5, pp: 761-765. Mar. 2015.

[5] Lakshmi Kumar Minapu, M K M V Ratnam, Dr. U Rangaraju " Experimental Study on Light Weight Aggregate Concrete with Pumice Stone, Silica Fume and Fly Ash as a Partial Replacement of Coarse Aggregate " International Journal of Innovative Research in Science, Engineering and Technology, (An ISO 3297: 2007 Certified Organization), Vol. 3, Issue 12, December 2014.

[6] Barbhuiya, S. A., Gbagbo, J. K., Russell, M. I. and Basheer, P. A. M " Properties of fly ash concrete modified with hydrated lime and silica fume "Construction and Building Materials, Vol. 23, 3233-3239,2009.

[7] Prabhat ranjain prem, B.H Bharatkumar and Nagesh iyer "Influence of curing regimes on compressive strength of concrete", Sadhana vol.38, Part 6, pp 1421-1431, dec 2013.

[8] A. Gonzalez-Corominas, M. Etxeberria, C.S. Poon, Influence of steam curing on the pore structures and mechanical properties of fly-ash high performance concrete prepared with recycled aggregates, Cement and Concrete Composites, doi: 10.1016/ j. cemconcomp. 2016.

[9] M. Ba, C. Qian, X. Guo, X. Han, Effects of steam curing on strength and porous structure of concrete with low water/binder ratio, Constr. Build. Mater. 25(2011)123-128. doi: 10.1016/j.conbuildmat.2010.

[10] Z. Wu, C. Shi, K.H. Khayat, S. Wan, Effects of Different Nanomaterials on Hardening and Performance of Ultra-High Strength Concrete (UHSC), Cement and Concrete Composites, doi: 10.1016/j.cemconcomp.2016.

[11] L.P. Singh, S.K. Bhattacharyya, S.P. Shah, G. Mishra, S. Ahalawat, U. Sharma " Studies on early stage hydration of tricalcium silicate in corporating silica Nano particles: Part I " Construction and Building Materials $74,278-286,2015$.

[12] Md. Kobir Hossain, Mohammad Abdur Rashid, and Md. Rezaul Karim; "Effect of Cement Content and Size of Coarse Aggregate on the Strength of Brick Aggregate Concrete" DUET Journal, Vol. 2, Issue 2, June 2015.

[13] ES (4756-1) part 1, "Compositing Specifications and Conformity Criteria for common cement “, Egyptian Organization for Standardization and Quality, Cairo, Egypt, 2009.

[14] E.S.S. No. 1109,"Aggregate", Egyptian Standard Specification, Ministry of Industry, Cairo, Egypt, 2008.

[15] British Standards Institution (BSI), BS EN 12390-3:2002: Testing hardened concrete Part 3: Compressive strength of test specimens, BSI, London, 2002. 